\title{
Saad Zaghloul \\ Pro- or Anti-Concession Extension of the Suez Canal \\ 1909-1910 \\ Rania Ali Maher
}

\begin{abstract}
The years 1909-1910 witnessed one of the most critical chapters in the history of the Suez Canal. The attempt of the British occupation to obtain ratification from the Egyptian General Assembly for extending the concession of the Suez Canal Company to 2008 made a great stir among the Egyptians and provoked new furies of national agitation against the British. Although there was a unanimous condemnation for the proposal, Saad Zaghloul played a different role in dealing with the problem. He staunchly defended the project in the Assembly that he had originally rejected, an act that caused many to accuse him of being complicit with the British. Despite the fact that the vehement opposition to the project led the Assembly to turn it down, Zaghloul's assessment of the situation raised a lot of questions concerning his involvement with the occupation and his relations with the Nationalists during this period. In light of the General Assembly Meetings, this paper is an endeavor to reveal the ambivalent role played by Zaghloul in this issue.
\end{abstract}

Keywords Saad Zaghloul - Suez Canal Concession - General Assembly Eldon Gorst.

\section{Introduction}

Since the time of the Denshway incident of 1906, Nationalist agitation against the British Occupation had increased steadily. By the second half of 1909 and the beginning of 1910, this anti-British sentiment came to a head with the attempts of Eldon Gorst, the British Consul-General (1907-1911) and of Butrus Pasha Ghali, the Prime Minister (1908-1910), to get an approval from the General Assembly for extending the Suez Canal concession for another forty years. As soon as the Egyptian intelligentsia got wind of it, numerous protests were made against the project and the Nationalist press had started an unrelenting campaign with the aim of forcing

the Assembly to reject the proposal. While a number of prominent national figures, such as Mohamed Farid, Abd Al-Aziz Ghawish, Ahmed Lutfi alSayyid and Ismail Abaza declared their resentment of the project and led a 
furious campaign against its execution, Saad Zaghloul, acting as the Minister of Justice (1910-1912), dissented their stances and defended the project before the Assembly, an action that placed him in the focus of nationalist criticism and sustained the allegations that leveled against him of being a deceitful politician. The main aim of this paper is not to exonerate or condemn Zaghloul, but to shed light on one of the salient episodes in the history of the prominent leader of the Nationalist movement and the most ardent opponent of the British occupation following the First World War, with an interpretation and analysis of the reasons that led him to defend the project that he had originally opposed.

\section{Zaghloul's Schism with the Nationalists}

After leaving Al-Azhar without obtaining his degree, Saad Zaghloul was appointed as an editor of the literary section of the Egyptian Official Journal "al-Waqai al-Misriyah" of which Sheikh Muhammad Abduh, his Professor, was chief editor. From there, he started his career in the government service where he first became an assistant in the Ministry of the Interior and then as overseer of the legal department in the province of Giza (Zaghloul, 1987).

With the breakdown of Urabi revolution, Zaghloul, who was one of its most fervent supporter and a close acquaintance of Abduh, was dismissed from his job and was deprived of his civil rights for a while (Zaghloul, 1987). So, Zaghloul took up the practice of law, where he proved to be of great success and was recognized as a distinguished orator and polemicist. Accordingly, he was appointed first as a judge in the Native Courts and then a Counselor at the Tribunal of Appeal (Adams, 1933). In 1897, he successfully obtained his degree of Law from France. Saad's achievements in his profession did not only bring him widespread recognition and wealth, but it also paved the way for him to rise among the Egyptian and European elites (Zaghloul, 1987). It was the political salon of Princess Nazli Fadhil', which he frequented, that

afforded him the opportunity of meeting with the British high officials, Sir Evelyn Baring, the Consul-General, Harry Boyle, Baring's Oriental

\footnotetext{
' Princess Nazli Fadhil was a niece of Khedive Ismail and the daughter of Prince Mustafa Fadhil, the son of Ibrahim Pasha. She hosted the first political salon in Cairo, where prominent public figures, poets, writers and jurists met and discussed the top stories of the day, the latest books and debated the political, economic and social Egyptian issues. Because of the reputation he gained in his legal practice, Zaghloul became her lawyer and her protégé. It was rumored that she was the one who arranged his marriage to Safiya Fahmi, the daughter of the Prime Minister Mustafa Fahmy Pasha, a matter that brought him to the heed of Lord Cromer (Talhami, 2013).
} 
Secretary, and also his future father-in-law, Mustafa Fahmy, the Pro-British Prime Minister (Zaghloul, 1987; Talhami, 2013; Al-Sayyid, 1977).

On the other hand, incessant condemnation by the European and the Egyptian public opinion, as a result of the brutality of Denshway incident, led Lord Cromer to believe that some concessions to the Egyptians were essential to mollify the critics of his policy in Egypt. He decided to give the Egyptians a larger share in the government (Owen, 2004) by appointing "one of the most distinguished members" of Abduh's party, Saad Zaghloul, as Minister of Education (Alexander, 1911: 342) after it had been upgraded from a department under the domination of the Ministry of Public Works to a separate Ministry (Owen, 2004). At that time, Cromer looked towards Abduh's group, as a crucial counterpoise to the fanatical and radical nationalism of Mustafa Kamel and his followers, whose program involved "not opposition to but cooperation with Europeans in the introduction of Western civilization into the country." (Alexander, 191: 81)

Cromer's nomination of Saad was not unpredictable, as he was an accomplished ex-government employee, a disciple of the collaborative Islamic reformer Muhammad Abduh, the protégé of Princess Nazli and the son-in-law of his faithful Prime Minister Fahmy (Bauval and Osman, 2012). Impressed by these factors, Cromer convinced Khedive Abbas, who was antagonistic to Abduh and his successors, to appoint Zaghloul as a Minister (Zaghloul 1987; Friedman 2012; Shafiq 1998), whom Cromer recognized as "an able man and enlightened Egyptian" (Alexander, 1911: 81-82).

The appointment of Zaghloul had been well received by all parties and "even the most uncompromisingly hostile (of) the native papers...expressed their approbation of the measure" (FO, 1906).

Profoundly influenced by the ideology of Islamic reform of Jamal al-Din alAfghani and Muhammad Abduh and believing that education was an essential constituent of Egypt's drive to self government, Saad Zaghloul stared his work in the Ministry with much more energy and with the vision to wrest whatever gains he could by cooperating with the British. Thus, it can be said that Zaghoul, during this period, was a moderate nationalist, who was not anti-British. He believed in the gradual development of the Egyptians to achieve the European moral and intellectual standard (Alexander, 1911). He expressed his vision very clearly in a statement he made to the Times

Newspaper in June 1907, saying: "We must assimilate Western methods; we must...alter our mentality, ...our methods and rules are inferior to theirs...When we intermingle with them [The British] and learn their sciences and their techniques, we can then cooperate with them for the benefit of our country........." (The Times, 1907: 4).

Despite Zaghloul's great endeavors in implementing changes in the Egyptian Education system within a short period of time (Russell, 2013; Cook, 2012), 
and his success, to a great extent, in asserting his authority against Dunlop the British Adviser to the Ministry, he became more than any other public figure the target of Nationalist attacks (Alexander 1911). He had his first encounter with the Nationalists when he resigned from the organizing committee responsible for the foundation of the first National University. Mustafa Kamil, the leader of the National Party, construed his withdrawal from the scheme as a kind of acquiescence to the British authority and a blow to the project (Al-Rafii, 1962; Shafiq, 1998). This rift was then aggravated when the General Assembly presented a proposal demanding that Arabic be the official language of instruction at governmental schools. Zaghloul, in a long speech before the Assembly, opposed the proposal. He claimed that this system would be a hindrance in front of the Egyptian education reform movements, as the Egyptian students could not benefit from the West without being proficient in their use and understanding of the English language. Furthermore, they would not be able to compete for numerous jobs that required linguistic abilities such as posts in customs, post office, mixed courts...etc. Despite Zaghloul's justifications for postponing the proposal to the appropriate time, the Assembly voted for its ratification, with only five members dissenting from the majority.

The resentment which the Nationalists felt towards Saad was verbalized in Kamel's scathing attack on him in al-Liwa Newspaper, writing: "People have now understood clearer than before why Lord Cromer has chosen for the Ministry of Public Education the son-in-law of the Prime Minister (Mustafa Fahmy Pasha), who is a custodian for his inspirations and a servant to his policies. Also, they have understood why the English newspapers and those biased to the British have thrown dust in everyone's eyes, stating that this new minister is of the National Party, while all his situations and his actions show his strong propensity to the [British] authority. Saad Pasha Zaghloul completely failed in front of the General Assembly.......... Those who used to respect the Minister as a lawyer, are enormously sorrowful for his present and appallingly fear for his future and extremely prefer his past...." (Al-Rafii, 1962: 415-416).

Accordingly, it can be concluded that Saad was actually in an absurd, untenable situation, as the Khedive and the militant Nationalists were clearly suspicious of him from one side and the British administration, from the other side, became massively disenchanted with him (Abi-Hamad, 2007), as he was not completely subservient to their authority, admitting that: "Until the appointment of Saad Pasha Zaghloul to the Ministry of Education (an impact from which it has hardly yet recovered) all was quiet on the Ministerial front." (Storrs, 1937: 76) 
Nevertheless, Zaghloul showed his appreciation and his gratitude to Cromer on the occasion of his retirement, saying gloomily to him: "I am not thinking of myself, but of my country and its interests, for it will lose a lot with your departure, a loss that can not be compensated." (Zaghloul, 1987: 231). He insisted on attending Cromer's farewell party and publically eulogized him, ignoring the criticism that could be leveled against him by the Khedive and his peers.

Cromer, in turn, highly praised Zaghloul in his farewell speech, saying: “... a career of great public usefulness lies before the present Minister of Education, Saad Zaghloul Pasha. He possesses all the qualities necessary to serve his country. He is honest; he is capable; he has the courage of his convictions; he has been abused by many of the less worthy of his own countrymen...He should go far." (Storrs, 1937: 52). These words reflected the good relation between the two.

On the other hand, Saad Zaghloul had managed to work congenially with Eldon Gorst, Cromer's successor, who had no cause to get rid of Saad, as he had shown great support to Cromer (Storrs, 1937). The reappointment of Zaghloul to the Ministry of Education in the new Cabinet of Butrus Pasha Ghali, despite the Khedive's reluctance ${ }^{r}$, and then his transition to the Ministry of Justice after the assassination of Ghali were irrefutable evidences of the confidence Gorst had in him. However, Zaghloul's memoirs reveal that he was clearly suspicious of Gorst's intentions towards him and that Gorst lost no opportunity to stimulate dissension among the Egyptian intelligentsia. In the meantime, Zaghloul suffered increasingly from Nationalist attacks to the extent that he had been accused by Mohammed Farid of being a tool in the hand of the British in order to achieve his goal of becoming prime minister, as promised previously by Lord Cromer (Zaghloul, 1987). Hence, it can be concluded that Zaghloul, during the early part of his public career, was

a "willing collaborator" with the occupation (Shafiq, 1998; Abi-Hamad, 2007), who believed that he could bring Egypt gradually to self-government through cooperation with the British in its program of administrative reform. This approach, by its turn, created serious breaches between him and the radical Nationalists and made his influence on the national movement unpretentious during this period (Bearce, 1949; Smith, 1972).

\section{The Project before the Assembly}

Realizing that the economic conditions of Egypt had been convoluted by a severe financial crisis and that the Egyptian government drastically needed

\footnotetext{
According to Shafiq, there was an agreement between the Khedive and Butrus Ghali to get rid of Saad after two or three months. Ghali promised the Khedive that he would find a way to force the Minister to leave (Shafiq, 1998).
} 
money to finance projects for the development of public works in Egypt and of railways in Sudan (Tignor, 2015), the Suez Canal Company offered Gorst the proposal of extending the Canal's concession ${ }^{r}$ for an additional forty years, from the year 1968 to the year 2008, in return for 4 million Egyptian pounds, payable to the Egyptian government in four equal installments between the period of December 1910 and December 1913, and an annual share from the Canal's revenue, rising from $4 \%$ in 1922 to $12 \%$ in 1961 (Shafiq, 1998). During the extended period, the annual profits of the Canal would be divided equally between the Company and the Egyptian Treasury, on the condition that the share of the Company would not be less than $50,000,000$ francs in any case. Egypt would also have the privilege of being represented in the Company Board by three members (Wilson, 1936; Alexander, 1911).

Believing that the project was "an excellent bargain for Egypt", Gorst, H. P. Harvey-the Financial Adviser, and Ghali secretly negotiated the details of the convention with the Company (Al-Sayyid, 1990; Hunter, 2007). However, in October 1909, a draft of the scheme was leaked out to Mohamed Farid -the chairman of the National Party, who published it in el-Liwa newspaper with the aim of stirring popular feeling against the project (Al-Rafii, 1984). As a result of the vigorous campaign led by the native press, hundreds of demonstrations were organized and more speeches were delivered denouncing the project and condemning the exploitation of the Egyptian resources by the British occupation (Badrawi, 2000). The fiercest point of attack on the project was that more than half of the amount of the money

would be used for the development of the Sudanese railways (Zaghloul, 1990; Al-Rafii, 1984). Thousands of telegrams were sent to the Khedive, Prime Minister, and Prince Hussan Kamil -President of the Legislative Council- asking for the submission of the convention of the proposed extension to the Legislative Council and the General Assembly before it was finally concluded (Al-Rafii, 1984; Alexander, 1911). In an attempt to shelter himself from the abuse of the local press and to quiet the agitation, Khedive Abbas decided to present the scheme before the General Assembly (Badrawi, 2000). Meanwhile, Gorst did not oppose the process, as he regarded it as a part of his policy of reviving Egypt's legislative institutions and of giving the Egyptians more proficiency in self-government (Tollefson, 1999; Weigall, 1915). Later on, he regretted this decision.

\footnotetext{
The idea of prolonging the concession of the Suez Canal was not a new one, as this issue was raised for several times in 1883, 1886 and 1890. The Company had then initiated it for the last time in October 1908 and it took almost a year of negotiation to finish the details of the convention and to submit it to the Egyptian government (Al-Sayyid 1990; Abbas II, 1930).
} 
While the British Treasury and the Board of Trade declared their reservations about the project (Hunter, 2007; Al-Sayyid, 1990), Sir Edward Grey, the Secretary of State for Foreign Affairs, announced in the House of the Commons that the proposed extension would be laid before the Egyptian General Assembly and it would be improper to debate the matter in Parliament before the General Assembly of Egypt proclaims its final decision (Wilson, 1936).

While some of the Egyptians ministers were expressing their apprehensions about the scheme, there were others who were completely hostile to it, deeming the proposed concession as a benefit merely to the Suez Canal Company and a detriment to Egypt. Nevertheless, Ghali and Gorst were managed to recruit their support to the project after long and strenuous discussions, to the extent that the latter complained about their "obstructions and stupidities" (Hunter, 2007: 216).

On $27^{\text {th }}$ of January 1910, the Council of the Ministers under the presidency of the Khedive unanimously arrived at the conclusion that the convention could be accepted if certain amendments were approved by the Company (Abbas II, 1998). On the same day, a Khedivial decree was issued to summon a meeting of the General Assembly on the $9^{\text {th }}$ of February for discussing the

scheme. Numerous of anonymous threatening letters were dispatched to the Prime Minister, the Ministers and the Members of the General Assembly warning them of accepting the bargain (Badrawi, 2000).

On these tempestuous scenes, Khedive Abbas inaugurated the unexceptional session of the General Assembly declaring that the approval of the government for the project was conditioned on the acceptance of the Company for the modifications of certain clauses. He asked the Assembly to examine the advantages and disadvantages of the proposed project for the country. He then pointed out to the fact that although the prolongation of the concession was not among the issues that the Council of Ministers was obliged, according to the Organic Law, to consult the General Assembly, but the government had decided, due to its exceptional importance to the present and the future generations, not to take a final decision before the Assembly

\footnotetext{
"The modifications demanded by the Council of Ministers were that the annual profits of the Canal should be divided equally between the Company and the Egyptian Treasury without any further deduction by the Company and this must start from 17 November 1968, the starting date of the extension instead from 1 January 1969. The article that stated that the Egyptian Government should cover the costs of the pensions owing to the Company's staff on the expiration date of the concession must be erased. In the same time, the Council refused to grant the Company the right of owning the lands that might be reclaimed from the sea as a result of the works that the Company would carry out in Port Said at its own expense, as these lands would be rendered to the common property service (Abbas II, 1998; Minutes of the General Assembly Meetings, 1910-1912).
} 
declared its conclusion regarding the scheme (Minutes of the General Assembly Meetings, 1910-1912). The Khedival speech was accompanied by a draft of the required amendments of the government for the convention and an explanatory note that elucidated the factors that might affect the consequent interests of Egypt in the Canal and its prospective value (Wilson, 1936; Alexander, 1911). On the following day, a special committee of fifteen members of the Assembly was formed to study the proposal of the government and to prepare a report (Davis, 1983). On the same session, Ismail Pasha Abaza, the leader of the opposition, raised another point of argument, by asking Ghali whether the government would be abided by the verdict of the Assembly or its decision was only consultative. Ghali declined the embroilment of his government in such a matter, as he evaded the question by proclaiming that nothing could be added to the Khedive's statement. After heated debate that lasted for almost an hour, the President of the Assembly was forced to adjourn the session (Wilson, 1936).

Ghali's defiance before the Assembly and his well-known support to the Suez Canal convention were among many other causes that led to his assassination on $20^{\text {th }}$ of February 1910 (The Egyptian Gazette, February 1910). Mohammed Pasha Said, who was known by his nationalistic tendency, was brought in to replace Ghali, in an attempt to appease the extremist Nationalists. Thus, the decision of submitting the convention before the General Assembly, the assassination of Butrus Ghali by Ibrahim El Wardani, who was fueled mainly by the Nationalist agitation against the project, and then the appointment of Said Pasha as a prime minister were

regarded as a victory for the militant cause and as a sign of docility of the occupation government (Alexander, 1911).

After five weeks of studying the scheme, the committee submitted its report to the General Assembly, advocating its rejection as expected ${ }^{\top}$. The report enclosed sharp criticisms of the government for their carelessness of preparing a detailed adequate study of the project. They concluded that the Assembly had no authority to modify the scheme. According to the proposed arrangements and careful calculation performed by the committee, the convention would cause about $f 130$ millions in losses for Egypt. The fears that the government had about future discoveries in the field of transit, which might reduce the importance of the Canal, were not based on reliable

\footnotetext{
- The Committee was originally consisted of nineteen members, but four of them decided to resign immediately after their election, avoiding being in confrontation with the Government and the public opinion (Zaghloul, 1990; Wilson 1936).

"As a result of the outcry from the Nationalist press against the project, most of the members of the committee had pledged themselves to not to support the project even before studying it (Alexander, 1911).
} 
evidences. They added that there was no clause for definite fiscal control of the Company. Also, the committee believed that there was no urgent financial need for renewing the concession in the present time and that the Company might offer better deal in the future (Alexander, 1911; Wilson, 1936).

On the other hand, it was decided by the new government, in order to calm the situation down, that the decision of the Assembly would be final (Badrawi, 2000). The role played by Saad Zaghloul -as a Minister of Justiceduring this stage is of particular significance, as he claimed that he was the one who seized the opportunity of being asked by Gorst to defend the project before the Assembly and asked for making the Assembly's decision binding to the government as a condition for his approval (Zaghloul, 1990). Accordingly, Gorst promised to let his government renounce the project in case that the Assembly would reject it (Shafiq, 1998).

\section{Saad Zaghloul and the Project}

On the $4^{\text {th }}$ of April 1910, the General Assembly met to discuss the report. As the sessions became public (Minutes of the General Assembly Meetings, 1910-1912), the upper visitors' galleries of the Assembly were overcrowded and even the building itself was surrounded by many demonstrators waiting for the Assembly's decision (The Egyptian Gazette, April 1910). Said Pasha, the new Prime Minister, opened the proceedings by recapitulating the Company's proposal, the amendments made by the government, the reports and the memoranda that discussed the project. He also noted that the government had several remarks on the committee's report that he entrusted to the consideration of the Assembly. He did not forget to recall the reasons for presenting the convention before the Assembly even though it was not among the issues that required its ratification. In the end, he announced that no assent would be given to the project without the Assembly's approval. The audience enthusiastically applauded the announcement (Wilson, 1936; The Egyptian Gazette, April 1910).

As per the deal with Gorst, Zaghloul, who was originally opposed the project, took the floor as the representative of the government and defended the scheme before the Assembly with a long speech that reflected his "convinced and unquestioning loyalty" in supporting it, as stated by the British parlance (Storrs, 1937: 80).

Zaghloul's speech caused a stir among the Nationalists and substantiated the allegations leveled at him by his detractors of being complicit with the British (Zaghloul, 1991).

Before assessing Zaghloul's defense of the project, it should be borne in mind that he was the one who headed the opposition to the project in the Council of Ministers. His diaries indicate that Gorst and Harvey accused him 
of stirring popular feeling against the scheme in an attempt to retrieve some of the reputability he had lost among the Nationalists (Zaghloul, 1990). He affirmed that the General Assembly would reject the project, saying to Harvey: "how can we convince someone with the benefits of the project that we are already refused." (Zaghloul, 1990; 134-135).

Zaghloul showed that he was completely supported by the Khedive, who advised him of not speaking openly about his opposition to the project, as this would draw the indignation and condemnation of the British (Zaghloul, 1990; Abbas II, 1930).

However, Zaghloul, in his meeting with Gorst on the $5^{\text {th }}$ of November 1909, declared that he was completely against the project, refusing to defend it or even to support Heshmat Pasha, the Minister of Finance, who was supposed to be responsible of defending the project before the Assembly. After a heated argument, and because of his tenacity, Gorst, at the end of the meeting, had nothing to say to Zaghloul except for asking him to not to show his resentment of the project publicly (Zaghloul, 1990).

Saad revealed that he was the one who foiled Gorst's and Ghlai's plot of having the immediate sanction of the government for the project before being submitted to the consideration of the Assembly and before getting the approval of the Company for the required modifications, as this would make future negotiations confined between the Company and the occupation, since they would already have the approval of the Egyptian government, and it would give the impression that the government unanimously was in favor of the extension (Zaghloul, 1990).

It is interesting here that Saad Zaghloul, in his meeting with Gorst on the $11^{\text {th }}$ of February 1910, criticized the government's negative approach in presenting the project before the Assembly. He stated that the government did not reveal the advantages and the benefits of the project to the country, allowing the members to look to the Nationalist press for a lead. In the same time, he declared that he had asked Ghali to give him the chance of defending the project before the committee, but Ghali refused because he was suspicious of Zaghloul's intentions. After a while, he claimed that the Khedive, who was opposing the project as previously mentioned, asked him many times to champion the cause before the Assembly (Zaghloul, 1990), then he contradicted what he said, proclaiming: "The Khedive did not want me to defend the project" (Zaghloul, 1991: 40). This clear contradiction in Zaghloul's statements can condemn him.

As mentioned before, Gorst accepted the idea of the General Assembly's arbitration, provided that Saad Zaghloul, who was identified as a talented speaker and debater, justified the scheme before it. Zaghloul, who was always suspicious of Gorst's intentions towards him, stated: "He wanted me 
to be exposed to the criticism of the nation, so that I may be weak in his hands." (Zaghloul, 1987: 474).

However, this was certainly regarded as a great triumph for the Nationalists cause and a step forward in giving the Egyptian representative institutions greater power.

On the other hand, Zaghloul expressed his wishes to be appointed as a president of the Legislative Council, after Hussein Kamel's resignation on $7^{\text {th }}$ of March 1910 owing to ill-health, and the press and the members' scathing attacks on him because of his supportive stance to the project (Fyfe, 1911; Alexander, 1911). Yet, Said Pasha assured him that he should be by his side as a Minister of Justice (Zaghloul, 1990). Zaghloul's wish to take up this position in a time when many of the leading figures refused to bear such responsibility raises a lot of questions, as he would be the president of the Assembly that would settle this exceptional important issue.

Before delivering his speech before the Assembly, Zaghloul asked Said Pasha to give him the right to announce the government grant to the Assembly of making its decision binding, as this would consolidate his position before the members and would alleviate the anger that he would face as a result of his speech. However, Said, as a Prime Minister, insisted that he was the one who should make this announcement (Zaghloul, 1990-1991).

In an elaborate and eloquent speech in favor of it, Zaghloul explicated the merits of the project, stressing that it was a purely financial issue and had nothing to do with politics. It did not mean the loss of the Canal, but it was only an extension of an already existent agreement that could not have an impact on the future of Egypt. He then proceeded to refute the committee's report. After almost an hour of speaking, he was exhausted and asked Sirry Pasha, Minister of Public Works, to continue reading his remarks from a printed memorandum. After a short time, he resumed his speech by clarifying that Egypt would be compelled by all means to make the passage in the Canal free when it reverted to it in 1969, and that the Company would be the only force that could induce the international powers to accept the continuance of paying the levies. He mentioned that the government would use the sum of money offered by the Company to develop various projects of reform. Sirry Pasha then discussed the irrigation and drainage projects, which could be implemented with this money. Zaghloul concluded his speech by urging the members to accept the project, which the government found "to be of great advantages to the country." (Minutes of the General Assembly Meetings, 1910-1912).

He denounced the idea of rejection based on the fact that the country had no control over public disbursement, saying: "It was a great error to deny the country the benefit of such great schemes merely because the country had no (constitution)." (The Egyptian Gazette, 1910: 3). He also announced that the government had received the approval of the Company for the required 
modifications on $20^{\text {th }}$ of February 1910, so the Council of Ministers did not bear the responsibility that "is now completely held by the members of the Assembly who have the upper hand in such matter."(Al-Rafii, 1984: 176). After finishing his speech, Zaghloul was "very loudly" cheered by the audience (The Gazette, April 1910). It should be noted that in his dairies, Zaghloul did not refer to the contents of his speech expect in one sentence, saying: "I did not have resentful feelings towards my defense for the project." (Zaghloul, 1990: 342).

On the $7^{\text {th }}$ of April, the Assembly resumed its discussion in what the Gazette described as "A Riotous Meeting" (The Egyptian Gazette April 1910). Abaza Pasha opened the debate by assuring that the government could not prove its case. Then Barakat Bey, Zaghloul's nephew and a member of the Assembly, took the floor to deliver the committee's reply to the government memorandum and Zaghloul's speech. He declared that it was planned to take the final vote for the scheme immediately after reading the said reply. After almost an hour, the hall rang with approval's shouts for the committee's reply that recommended again the rejection of the scheme. Zaghloul, who had been showing signs of disapproval, tried to stand and to speak in the midst of this clutter. Abaza Pasha rose and asked the President to take vote at once for the project, as the debate on the subject had been finished and closed. Zaghloul refused furiously to yield to the order of some members, shouting: "By what right do you want to prevent a member of the Assembly from making his statement and you interrupt him?" He expressed his wishes to get more time to pronounce his remarks on the committee's last report that were imperative, as the report had been kept secret. He then deprecated the methods they wanted to follow, saying: "we are not regarded ourselves as two different parties in a lawsuit, but we are members of the same body and same assembly that are working for the benefits of our country...no member has the right to enforce silence upon another if he has a different opinion. You are now acting against the liberty of speech, a principle that you should defend by all means. The very procedure you are now using against me will be used against you one day. You are committing a great error by employing this procedure. You have the upper hand to either listen to all that can be said on the subject before taking your final decision or you can silence me and take this crucial decision without hearing the government's observations."

Abaza Pasha retorted in a long speech that every argument should have an end. If they gave the government the time to study this last report and to later reply, there would be no end to this issue, and the Suez Canal's present concession would expire and the scheme would be still under negotiation.

Zaghloul then rose again and confirmed that the members of the Assembly were the ones who held such great responsibility, as they were the judges for such a scheme and the government was the lawyer, so "how can the judges 
prevent the lawyer from defending and clarifying his case...By allowing me to declare all the required explanations of the government, I am serving you better than those who are trying to silence me..." (Minutes of the General Assembly Meetings, 1910-1912).

Zaghloul was only supported by Shawrai Pasha and Semaki Bey, so his attempts were to no avail and the Assembly voted by a great majority for the closing of the decision and then the entire Assembly, except for the Ministers and Semaki Bey, voted for the rejection of the project in the middle of boisterous applause and cheering (Semaki, 2011). Outside the building, about 15000 demonstrators started to march on the streets with music and banners celebrating the rejection of the project, chanting: "Long live" the members of the Assembly and the leaders of Nationalists, "Down with the Army of Occupation" and "Down with England".

Despite the official denial of the government, it became popularly known that there was a "secret agreement" between the Ministers and the Assembly for the rejection of the scheme. Former ministers and high officials asserted that the present-day Ministers were reluctant to the extension of the concession even though they were pretending that they were supporting it, as they wanted to retain their posts. This can explain why the members of the Assembly and demonstrators began to praise the Ministers as soon as the final decision of the Assembly was announced, shouting, "Long live the Said's Ministry" (The Egyptian Gazette, April 1910: 3)

Nevertheless, this common belief created "Ministerial Crisis", as it was rumored that Zaghloul had "wrung" this official disavowal from Said Pasha after great difficulty (The Egyptian Gazette, April 1910). He blamed all of his colleagues for not supporting him in front of the Assembly and declared that there was a secret agreement between them and the members of the Assembly of preventing him from continuing the discussion, as they believed that he would handle the subject in a way that could harm the country (Zaghloul, 1990). According to the Gazette, Zaghloul's sincere defense for the project was linked by his ambition to be a prime minister, writing: "Zaghloul Pasha who was publicly designated by Lord Cromer as a future premier has not forgotten his old claim to the higher post...." (The Egyptian Gazette, April 1910: 3).

His audacious defense before the Assembly had drawn the ire and the condemnation of the Nationalist papers to the extent that he was accused of being a traitor to his country, as they assumed that he tried secretly to gain the support of some members of the Assembly for the project (Zaghloul, 1990-1991).

Zaghloul, by his turn, had assured some of his friends that he was totally sincere in his defense of the project (The Egyptian Gazette, April 1910). As after a long and adequate study for the matter, he came to the conclusion that unless the Suez Canal Company continued its administration for the Canal 


\section{Saad Zaghloul \\ Pro- or Anti-Concession Extension of the Suez Canal 1909-1910}

after 1969, Egypt would lose its revenue from it, as the Canal would not be reverted back to the country and would be regarded as a common property of all nations according to the existing concession (Zaghloul, 1990).

Zaghloul, in his dairies, did not demonstrate any reasonable justifications for his defiant defense expect for claiming that they had wrested from Gorst the privilege of making the Assembly's decision conclusive in return for their promise of defending the project, so they had to keep their promise and to act in an honorable way, otherwise they would be accused of dereliction and complicity (Zaghloul, 1990).

It is also noteworthy here that Abd al-Atheem Ramadan -the editor of Zaghloul's memoirs- who refuted all of Zaghloul's wrongdoings while he was a Minister, did not try to make any justifications for Zaghloul's actions towards the Suez Canal's question and he evaded this issue.

In the time that the Egyptians regarded the Assembly's rejection of the extension of the Suez Canal concession as the first real nationalist achievement since the beginning of the British occupation, Gorst described this experiment as "one of the fatal mistakes of our policy in the Near East." (Alexander, 1911: 329). He criticized the procedures adopted by the Assembly, saying: "...I did not anticipate such an open and indecent refusal even to discuss the question..." (Hunter, 2007: 221), a matter that Zaghloul warned about. Gorst exploited the situation to prove that the Egyptians were not prepared yet for self-government (Richmond, 1977), blaming the Ministers for their incompetence in performing their duties, as they showed "great weakness and their only idea (was) to take the line of least resistance."(Hunter, 2007: 221). As Gorst made the case to Grey, he believed "that the policy of ruling this country in cooperation with native ministers is, at the present time, incompatible with that of encouraging the development of the so-called representative institutions." (Darwin, 1981: 57).

\section{Conclusions}

It is undeniable that Zaghloul started his public career as a moderate Nationalist who believed in the necessity of reform prior to independence and the gradual progression towards self-government with the support of the British. Despite his successful attempts in asserting his authority against the British advisers, Zaghloul had managed to reach compromises with both Cromer and Gorst and he never opposed their policies sharply. However, in his way to carry out his reform project, a serious rupture occurred between him and the extreme Nationalists, and he became the object of their criticisms from 1906 and down to 1910. He was always accused of being interested in his personal position than in the National cause. 
It can be said that Zaghloul's political vision during this period is very well illustrated in his attitude towards the Suez Canal episode. As previously mentioned, his initial actions showed that he was determined to oppose the project violently. His memoirs indicate that he was like all the Nationalists, who regarded the project as a continuation of Egypt servitude and a detriment to the country. Later on he changed his position and defended the project before the General Assembly according to Gorst's bargain. It is quite difficult to arrive at an exact illation for Zaghloul's actions regarding this issue, but what's clear is that he himself frankly acknowledged that Egypt would not benefit from the Canal in all cases. Thus, he might have wanted to use the subject to advance Egypt on the way of self-government and to prove for the civilized world that Egypt was fitted for Parliamentary government and its institutions were followed the democratic procedures. This may explain why Zaghloul denounced the Assembly proceeding and condemned Abaza Pasha for his actions. Whatever the reasons that led Zaghloul to change his position, the fact remains that he was the one who dissented the stance of all the

Nationalists and defended the project, which was bitterly opposed by the Egyptians.

\section{References}

\section{Primary Sources}

- The National Archives of the United Kingdom: Public Records Office 1 (PRO), Foreign Office Records, FO 371/67, Cromer to Sir Edward Grey, November 2nd, 1906.

- Minutes of the Egyptian General Assembly Meetings (1910-1912). Mostafa El-Gharib Mohamed (Ed.), Vol. II, Cairo: Dar el-Kotb we elWathaeq el-Qawmih, p.31-48, 395-403, 481-511.

\section{Memoirs}

- Abbas II, Khedive of Egypt (1930). A Few Words on the AngloEgyptian Settlement, London: G. Allen \& Unwin Limited, p. 34-36.

- Abbas II, Khedive of Egypt (1998). The Last Khedive of Egypt: Memoirs of Abbas Hilmi II, Amira El- Azhary Sonbol (Ed.), Ithaca Press, p. 265-269.

- Shafiq, Ahmed (1998). Muzakarati fi Nisf Qarn, Vol. III, Cairo: alHay'ah al-Misriyah al-'Amah lil-Kitab, p. 102, 110, 160-161, 186187.

- Storrs, Sir Ronald (1937). The Memoirs of Sir Ronald Storrs, The Van Rees Press, New York, p. 52, 76, 80, 99.

- Zaghloul, Saad (1987-1991). Saad Zaghlul's Diaries. Abd Al-Atheem Ramadan (Ed.), Vols. I- IV, Cairo: al-Hay'ah al-Misriyah al-'amah lil- 
Kitab, Vol. I, p. 55, 60,64, 68, 73, 110, 231, 400, 472,464; Vol. III, p. $115,122-123,127,129,131,134-136,142-144,184,302-308,317$, 329-330, 331-332, 337-338, 340-344; Vol. IV, p. 39-40.

\section{Secondary Sources}

- Adams, Charles C. (1933). Islam and Modernism in Egypt, London: Oxford Univ. Press, p. 228.

- Al-Rafii, Abd al-Rihman (1962). Mustafa Kamil Ba ith al-Haraka alWataniyah: Tarikh Misr al-Qawmi min Sanat 1892 ila Sanat 1908, Cairo: Maktabat al-Nahdah al- Misriyah, p. 415-416.

- Al-Rafii, Abd al-Rihman (1984). Mohamed Farid Ramez al-Ekhlas we ai-Tadhiah: Tarikh Misr al-Qawmi min Sanat 1908 ila Sanat 1991, Cairo: Dar al-Ma 'aref, p. 152, 155-156, 161, 176.

- Al-Sayyid, Afaf Lutfi (1977). Egypt's Liberal Experiment, 19221936, University of California Press, p. 46.

- Al-Sayyid, Hussien Galal (1990). Mu'ammaret Mad Imtiyaz Qanat al-Suwaiss 1908-1910, Cairo: al-Hay'ah al-Misriyah al-'Amah lilKitab, p. 11-26, 55-63, 200.

- Alexander, J. (1911). The Truth about Egypt, Cassell, p. 55, 81-82, 110, 193, 285-286, 304-306, 312, 324-326, 329 .

- Badrawi, Malak (2000). Political Violence in Egypt, 1910-1924: Secret Societies, Plots and Assassinations, Curzon Press, p. 8-15, 31, 43.

- Bauval, Robert \& Osman, Ahmed (2012). Breaking the Mirror of Heaven: The Conspiracy to Suppress the Voice of Ancient Egypt, Simon and Schuster.

- Cook, Steven A. (2012). The Struggle for Egypt from Nasser to Tahrir Square, Oxford University Press, p. 16.

- Darwin, John (1981). Britain, Egypt and the Middle East: Imperial Policy in the Aftermath of War, 1918-1922, Macmillan Press, p. 57.

- Davis, Eric (1983). Challenging Colonialism: Bank Misr and Egyptian Industrialization, 1920-1941, Princeton, N.J.: Princeton University Press, p. 105.

- Friedman, Isaiah, (2012). British Miscalculations: The Rise of Muslim Nationalism, 1918-1925, Transaction Publishers, New Brunswick, New Jersey, p. 75.

- Fyfe, H. Hamilton (1911). The New Spirit in Egypt, William Blackwood and Sons, Edinburgh and London, p. 135, 139.

- Hunter, Archie (2007). Power and Passion in Egypt: A life of Sir Eldon Gorst, 1861-1911, I.B.Taruis, p. 213, 215-216, 221. 
- McPherson, Joseph Williams \& Carman, Barry \& McPherson, John, (1983). The Man who loved Egypt: Bimbashi McPherson, British Broadcasting Corp, p. 74.

- Owen, Roger (2004). Lord Cromer: Victorian Imperialist, Edwardian Proconsul, Oxford University Press, Oxford; New York, p. 342.

- Richmond, John C.B. (1977). Egypt, 1798-1952: Her Advance Towards a Modern Identity, Columbia University Press, p. 162.

- Russell, Mona L. (2013). Middle East in Focus: Egypt, ABC- Clio, LLC, p. 193.

- Semaki, Samir Mahfouz (2011). Marcus Pasha Simaika Founder of the Coptic Museum; His Life and Times, Cairo: Farid Atiya Press, p. 43.

- Talhami, Ghad Hashem (2013). Historical Dictionary of Women in the Middle East and North Africa, Rowman \& Littlefield, p. 117.

- Tignor, Robert L. (2015). Modernization and British Colonial Rule in Egypt, 1882-1914, Princeton University Press, p. 312.

- Tollefson, Harold (1999). Policing Islam: The British Occupation of Egypt and the Anglo-Egyptian Struggle over Control of the Police, 1882-1914, Greenwood Publishing Group, p. 139, 147.

- Weigall, Arthur E. P. Brome (1915). A History of Events in Egypt from 1798 to 1914, Charles Scribner's Sons, p. 229.

- Wilson, Sir Arnold T. (1936). The Suez Canal, its Past, Present and Future, Oxford University Press, London: Humphrey Milford, p. 9599.

\section{Journals and Newspapers}

- The Times (1907, June 6), p. 4.

- The Egyptian Gazette (1910, February 21), p. 3.

- The Egyptian Gazette (1910, April 5), p. 3.

- The Egyptian Gazette (1910, April 8), p. 3.

- The Egyptian Gazette (1910, April 13), p. 3.

- The Egyptian Gazette (1910, April 15), p. 3.

\section{Theses and Dissertations}

- Abi-Hamad, Saad Ghazi (2007). Dueling Perceptions: British and Egyptian Interactions, 1882-1919, PH.D Thesis, Faculty of the Graduate School, University of Texas at Austin, p. 3, 77-78.

- Bearce, George Donham (1994). Saad Zaghloul and Egyptian Nationalism, Master Thesis, Faculty of Arts, University of Wisconsin, p, 20-22, 31.

- Smith, Russell Yates (1972). The Making of an Egyptian Nationalist: The Political Career of Saad Zaghloul Pasha Prior to 1919, PH.D. Thesis, The Graduate School of Ohio State University, p.51-52. 